\title{
Evaluation of the use of tomography in penetrating neck trauma
}

\section{Avaliação da utilização da tomografia computadorizada no trauma cervical penetrante}

\author{
Adonis Nasr, TCBC-PRㅜ; Jéssica Tamara de Oliveira ${ }^{1}$; Melissa Mello Mazepa ${ }^{1}$; Christine lima Cavalcanti de Albuquerque²; \\ Gabriela Soraya MartinI²; Mariana Nazario²; Fábio Henrique de Carvalho, ACBC-PR ${ }^{1}$
}

A B S T R A C T

\begin{abstract}
Objective: the study has the intention of evaluate the accuracy of computed tomography for the diagnosis of cervical lesions on penetrating neck trauma and also identify the most frequent mechanisms of trauma. Most injured structures, determine the age range and the most prevalent sex. Methods: observational descriptive retrospective study executed by the systematic retrospective review of medical records of all patients victims of penetrating neck trauma that went through surgery and CT scans, admitted into Hospital do Trabalhador, between January 2009 and December 2013. Results: the final sample was of 30 patients, $96.7 \%$ of the male sex, the median age was of 28 years old. Most patients suffered injuries by gun (56.7\%) and 33,3\% suffered stab wounds. The most stricken area of the neck was Zone II (77.8\%) and the left side (55.2\%). Regarding the structures injured, the CT showed $6.7 \%$ lesions on airways but the surgery showed $40 \%$ of damaged, with a value of $p=0.002$. As to damages of the esophagus and pharynx the $\mathrm{CT}$ detected $10 \%$ of lesions, while surgery found $30 \%$ of lesions, therefore with a significant value of $p=0.013$. As for the analysis the $\mathrm{CT}$ showed reliable. As for the analysis of vascular damage, the CT showed to be, in most cases, reliable to the findings during the surgical act. Conclusion: besides the great use of CT for the diagnosis of penetrating neck injuries we can say that this is an exam with low accuracy for the diagnosis of lesions of aerodigestive tract, therefore it is important a clinical correlation for a good diagnosis.as for the vascular lesions and of other structures, the CT had high sensibility and specificity, thus a good exam to be used in overall.
\end{abstract}

Key words: Neck Injuries. Wounds and Injuries. Diagnostic Imaging. Tomography, X-Ray Computed.

\section{INTRODUCTION}

P enetrating cervical injuries has been a major trauma mechanism, present in about $5-10 \%$ of trauma patients, with an estimated mortality of 3-10\% ${ }^{1}$. Penetrating injuries are most commonly caused by fire gun, a mechanism that has higher mortality ${ }^{2,3}$. Anatomically, the neck is a region that contains a great amount of important structures vascular, respiratory, digestive and nerve - in a small, confined space ${ }^{4}$ so that injuries in this region has a tendency to achieve several vital structures. The evaluation and treatment of cervical penetrating wounds are still difficult to handle. There is currently a great debate on the approach to be adopted in such injuries and the operative management has been replaced by a more selective and conservative approach ${ }^{5,6}$.

Cervical components most often injured in penetrating trauma are related to vascular injuries (21-27\%), followed by spinal cord (16\%) and aero digestive tract (6$10 \%)$ as the larynx or trachea and pharynx or esophagus ${ }^{2,4,7}$. There is a predominance of young patients and male victims of these injuries, aged in the third and fourth decades of life $\mathrm{e}^{2,8}$.
The diagnosis can be made by physical examination alone, or aided by additional tests such as radiography performed in three incidents (lateral, anteroposterior and trans-oral), computed tomography (CT) and magnetic resonance imaging (MRI). Currently, several studies indicate that the method of would be computed angiography, since it is a relatively quick scan, high resolution and with a sensitivity of $98 \%$, plus it is an exam easily accessible and generally available in most services trauma ${ }^{9}$.

The medical management in these cases is still controversial. The mandatory exploratory cervicotomy, previously recommended in these cases, is falling into disuse, lead to a large number of non-therapeutic surgical procedures ${ }^{1}$. Patients who underwent immediate surgical treatment are those with heavy bleeding, hemodynamic instability, dysphonia, air leakage, injury diagnosed on CT, platisma perforation, transcervical injuries by gunshot and subcutaneous emphysema ${ }^{10}$. The other cases should be carefully evaluated through physical examination and CT scan, to later be performed surgery if necessary ${ }^{11}$.

Due to the complexity of the approach of these cases and the importance of imaging exam in the evaluation

1. Universidade Federal do Paraná (UFPR) - PR - Brasil; 2. Universidade Positivo - PR - Brasil. 
of the patient, this study aims to evaluate the accuracy of computed tomography in the diagnosis of cervical injuries in penetrating cervical trauma. Also, determine the epidemiology of affected patients and to recognize the regions and structures of the neck most commonly injured structures.

\section{METHODS}

The Hospital do Trabalhador $(\mathrm{HT})$ is a center of excellence in trauma care patient, located in Curitiba, Paraná. It is responsible for the care of approximately $60 \%$ of urgency and emergency care of Curitiba and metropolitan region, it is considered a teaching hospital, a reference in training human resources for health ${ }^{12}$. The Emergency Room of Hospital do Trabalhador (ER-HT) in Curitiba, State of Paraná, operates in a dual mechanism for admitting patients: spontaneous demand and referenced (SIATE/ SAMU). In 2012, the PS-HT attended 63,855 patients, and the highest percentage of this number was made up of accident victims ${ }^{12}$.

This is a retrospective, descriptive and observational study. The study included patients suffering from penetrating cervical trauma who underwent CT scans at admission and subsequently underwent a surgical procedure to correct possible injury. The open surgical approach was considered the gold standard in this study for comparison with the findings of the CT scan. We analyzed all records of patients older than 18 years, admitted to the Hospital do Trabalhador between January 2009 and December 2013.

We collect epidemiological data of the study sample, such as age and gender, mechanism of injury, signs and symptoms on admission, complementary tests, findings of computed tomography, surgical findings, established treatment, complications and associated injuries to the cervical trauma. Data were collected and stored, checked, exported and statistically analyzed. We consider $p<0.05$ statistically significant.

\section{RESULTS}

The final sample consisted of 30 patients who met the inclusion criteria, $96.7 \%$ were male and only $3.3 \%$ were female. The ages ranged between 14 and 66 years, and the median age was 28 years. Regarding the mechanism of injury, $56.7 \%$ suffered injury by gunshot wounds and $33.3 \%$, stab wound, other mechanisms were responsible for $10 \%$ of the lesions. Regarding the location of the entrance to injury, the neck zone 2 was the most commonly achieved in $77.8 \%$, followed by zone $1,22.2 \%$. Thewounds on the left side corresponding to $55.2 \%$ of the sample, $34.5 \%$ on the right side and $10.3 \%$ of anterior lesions.
Pre admission data showed that most patients have stable vital signs (86.3\%), $87 \%$ of the patients were normotensive in the prehospital exam and $13 \%$ were hypotensive. The airway was pervious in $79.3 \%$ of cases, $10.3 \%$ required intubation and mechanical ventilation. Only $13.7 \%$ of patients had lower scores than 8 on the Glasgow Coma Scale (GCS) on admission, the remaining 88.3\% had ECG greater than 11.

The most common signs of injury in penetrating cervical trauma observed on physical examination on admission in hospital were evaluated, $65.5 \%$ of the sample had active bleeding injury, $17.2 \%$ hematomas, $6.9 \%$ had stridor and only one had dysphonia. Subcutaneous emphysema was observed in $27.6 \%$ of cases.

Comparing the data observed on CT angiography with the data of the open surgical procedure, considered the gold standard in this study, we found injuries of carotid arteries in $6.7 \%$ of the sample in the CT and $16.7 \%$ in surgery. As for the jugular veins, 16.7\% were injured in CT and $23.3 \%$ in cervicotomy (Table 1). The vertebral arteries were injured in $13.3 \%$ on imaging exam and only $3.3 \%$ in surgery. Injuries in other arteries were found in surgery in $10 \%$ of cases and on CT in only $3.3 \%$. As the airways, the tomography showed $6.7 \%$ of alterations, while surgery found $40 \%$ of injuries, this data has statistical significance, with $p=0.002$. In angiography had esophageal and pharynx damage $10 \%$ of patients, compared to $30 \%$ in open surgery, data that also presented significance with $p=0.013$. We found thyroid injuries in $20.7 \%$ of patients in angiography and $10.3 \%$ during the cervicotomy $(p=0.375)$.

As treatment of vascular injuries found in the exploratory cervicotomy in $26.7 \%$ of patients suture of veins were required and in $23.3 \%$ suture of arteries. No grafts were used, but ligature and prosthesis were made in 3.3\% of patients and two people received drain. Tracheostomy was performed in $33.3 \%$ of cases, laryngeal suture in $20 \%$, suture elsewhere as pharynx in one case and esophagus in two cases. It was found simultaneous injury to the larynx and esophagus in one patient and injury to the trachea associated with larynx also in one patient.

The postoperative complications were neurological deficit, esophagus cutaneous fistula, bleeding and neck infection were less prevalent (Table 2). Only one patient died. Six patients (20\%) had gunshot wound the chest simultaneously, one patient had head trauma.

\section{DISCUSSION}

The penetrating cervical injuries are of high complexity due to the presence of a large amount of vital structures housed in a small space, resulting at high rates of morbidity. Moreover, these injuries can be interpreted as evidence of increasing at urban violence and therefore it is really worth mentioning this in trauma services ${ }^{7,9}$. 
Table 1 - Comparison of the injuries found in CT angiography with those found in open surgery.

\begin{tabular}{|c|c|c|c|}
\hline Injured structure & $\begin{array}{c}\text { CT angiography } \\
\mathrm{N}(\%)\end{array}$ & $\begin{array}{l}\text { Surgery } \\
\mathrm{N}(\%)\end{array}$ & $P$ value \\
\hline Right CCA & $1 \quad(3.3 \%)$ & $2 \quad(6.7 \%)$ & - \\
\hline Left CCA & 0 & $(3.3 \%)$ & 1 \\
\hline Right ICA & $1 \quad(3.3 \%)$ & $(6.7 \%)$ & 1 \\
\hline Left ICA & 0 & - & \\
\hline Right IJV & $2 \quad(6.7 \%)$ & $4 \quad(13.3 \%)$ & 0.500 \\
\hline Left IJV & $1 \quad(3.3 \%$ & $1 \quad(3.3 \%)$ & 1 \\
\hline Right EJV & $1 \quad(3.3 \%)$ & 0 & 1 \\
\hline Left EJV & $1 \quad(3.3 \%)$ & $(6.7 \%)$ & 1 \\
\hline Right vertebral artery & $2 \quad(6.7 \%)$ & $(3.3 \%)$ & 1 \\
\hline Left vertebral artery & $2 \quad(6.7 \%)$ & 0 & 0.500 \\
\hline Airways & $(6.7 \%)$ & $(40 \%)$ & 0.002 \\
\hline Esophageal/pharynx & $3 \quad(10 \%)$ & $(30 \%)$ & 0.013 \\
\hline Thyroid & $6 \quad(20.7 \%)$ & $3 \quad(10.3 \%)$ & 0.375 \\
\hline
\end{tabular}

N: number; CCA: Common carotid artery; ICA: Internal carotid artery; IJV: Internal jugular vein; EJV: External jugular vein.

The neck corresponds to a region of great importance in the management of trauma, the injuries can be penetrating when they exceed the platysma or superficial injuries when do not. Anatomically it is divided into three zones (I, II and III). Zone I is bounded by the cricoid cartilage, sternum and clavicle. In this region are located structures such as arteries and veins subclavian, common carotid artery, trachea, esophagus, thoracic duct, and nerves recurrent laryngeal and vague. Zone II is the one with higher incidence of lesões ${ }^{2}$ and it has as lower limit the cricoid cartilage and the superior angle of the jaw, and its main structures are the larynx, pharynx, carotid arteries and jugular veins. The zone III is located between the angle of the mandible and the skull base and contains the internal and external carotid, vertebral artery and the sympathetic trunk ${ }^{7,13}$.

According Muneraet al. ${ }^{14}$ penetrating injuries of the neck leading to mortality rate ranging between 2 and $10 \%$ and morbidity of $5 \%$. The carotid lesions and vertebral arteries are the main factors that determine the prognosis of patients, and they are account for a large number of complications and sequelae resulting from trauma. However, until now there are controversies about the best method to diagnosis these injuries ${ }^{14,15}$.

In our research, as well as in other studies, we obtained a predominance of males with $96.7 \%$ of cases, other study have shown a male prevalence also around $90 \%{ }^{2}$. It was also compatible the age, 28 at our study, in other words, most young adults ${ }^{2}$. About the most affected areas, the II was the most one $(77.8 \%)$, similar as found in the reviewed studies $7,16-18$.

It is known that the clinical examination may be sufficient to identify the injured structures at neck trauma thus leading to diagnosis. As physical examination findings, $70 \%$ of patients with vascular lesions showed bleeding type
Table 2 - Postoperative complications.

\begin{tabular}{lcc}
\hline Complications & $\mathrm{N}$ & $\%$ \\
\hline Neurological déficit & 2 & 6.66 \\
Esophageal-cutaneous fistula & 2 & 6.66 \\
Infection & 1 & 3.33 \\
Bleeding & 1 & 3.33 \\
Death & 1 & 3.33 \\
\hline
\end{tabular}

'drooling' on admission, do not been characterized as big bleeding or expanding hematoma, which allowed doing research imaging tests. At airway, esophagus and pharynx lesions, we do not obtained specific signs, however the esophageal lesions are known to be usually asymptomatic until the moment of very severe situation 10,19,20.

Currently, CT angiography has been a noninvasive method, effective and readily available for evaluation of neck trauma, reducing significantly the number of surgical procedures, as well as non-therapeutic cervicotomy, therefore, it is replacing previously tests performed, such as angiography or $\mathrm{MR}^{21}$.

Studies show that CT angiography has a high capacity diagnosed mainly in identifying lesions at arteries and veins of the neck, with a specificity of about $100 \%$ and sensitivity of $90 \%$. This fact was confirmed in our study, since tomography identified blood vessels lesions, which, for the most part, were corroborated by surgery ${ }^{15,22}$.

Regarding the airways and digestive tract, it is known that injuries are associated with high morbidity and mortality trauma, which may lead to complications such as sepsis mediastinine and, therefore the diagnosis is of 
paramount importance. In our study, CT was shown to be an examination with low diagnostic sensitivity for this type of injury, and in 54\% of cases the examination did not identify airway changes or digestive tract, which were present at the time of surgical exploration, presenting a $p$ value with statistical significance $(p=0.002$ and $p=0.013$, respectively).

Regarding the treatment of penetratinginjuries of the cervical blood vessels, the preference was for surgical repair at the expense of vascular ligation, except in the case of coma associated with absence of anterograde flow ${ }^{23}$. In the present study, $100 \%$ of arterial lesions were treated with reconstruction of the blood vessel.

The airway lesions were managed with pre-hospital orotracheal intubation at $16.67 \%$, a tracheostomy was performed in $75 \%$ of patients, $50 \%$ required suture at laryngeal/tracheal. There is need early intervention in airway injury at penetrating neck trauma, tracheal intubation is indicated in most cases, but in this study the majority of the sample was conducted with tracheostomy. The primary suture tends to good results, and so was the treatment used at who required surgical intervention ${ }^{24}$.

Finally, we noted in this study that CT shown not to be one of the best options to make the diagnosis of airway and digestive tract injuries in penetrating neck trauma. What highlights the need for a high index of suspicion and the correlation with physical examination data for a more accurate diagnosis of alterations involving these structures ${ }^{1,9,11,25-27}$. However, this is a test available in most trauma services, besides being a non-invasive, relatively rapid achievement test and which can evaluate different structures at the same time. CT angiography is also the method of choice for the diagnosis of vascular damage in penetrating neck trauma, which do not allow us to reduce the importance of the exam.

We have found some limitations throughout the study regarding at the fill to the form of patients and the book of computed tomography during some periods of time. Patients included in the study are part of a select group of individuals, which were stable during the initial approach, enabling the realization of research imaging tests and therefore feature a bias for research. Therefore, we emphasize the importance of further studies on the subject, especially with regard to the diagnosis of airway and digestive tract lesions.

In conclusion, besides the great use of CT for the diagnosis of penetrating neck injuries we can say that this is an exam with low accuracy for the diagnosis of lesions of aerodigestive tract, therefore it is a important clinical correlation for a good diagnosis. As for the vascular lesions and of other structures, the CT had high sensibility and specificity, thus a good exam to be used in overall.

\title{
RE S U M O
}

\begin{abstract}
Objetivo: avaliar a acurácia da tomografia computadorizada no diagnóstico de lesões do trauma cervical penetrante. Métodos: estudo retrospectivo descritivo observacional realizado através da revisão de prontuários de todos os pacientes vítimas de trauma cervical penetrante que foram operados e submetidos à tomografia computadorizada no pré-operatório. Resultados: a amostra final compreendeu 30 pacientes, sendo 96,7\% do sexo masculino e a mediana de idade foi 28 anos. A maioria dos pacientes sofreu ferimento por arma de fogo (FAF) em 56,7\% dos casos e 33,3\% foram ferimentos por arma branca (FAB). A zona do pescoço mais acometido foi a zona II (77,8\%) e no lado esquerdo (55,2\%). Em relação às estruturas lesadas, a tomografia computadorizada (TC) mostrou $6,7 \%$ de lesões em vias aéreas e durante a operação encontrou-se $40 \%$ de alterações $(p=0,002)$. A tomografia computadorizada detectou $10 \%$ de leões do esôfago e faringe, durante a operação encontrou-se $30 \%$ de lesões ( $p=0,013)$. Já, para análise de danos vasculares, a TC se mostrou, na maioria dos casos, fidedigna aos achados durante o procedimento operatório. Conclusão: apesar do grande uso da tomografia computadorizada no diagnóstico de lesões cervicais penetrantes, pode-se afirmar que este é um exame com baixa acurácia no diagnóstico de lesões de trato aerodigestivo, sendo importante uma correlação clínica para um bom diagnóstico. Já para lesões vasculares e de outras estruturas, a TC apresentou alto grau de sensibilidade e especificidade, sendo assim um bom exame a ser utilizado nesses casos.
\end{abstract}

Descritores: Lesões do Pescoço. Ferimentos e Lesões. Diagnóstico por Imagem. Tomografia Computadorizada por Raios X.

\section{REFERENCES}

1. Demetriades D, Skalkides J, Sofianos C, Melissas J, Franklin J. Carotid artery injuries: experience with 124 cases. J Trauma. 1989;29(1):91-4.

2. Bahten LCV, Duda JR, Zanatta PDS, Morais AL, Silveira F, Olandoski M. Ferimentos cervicais: análise retrospectiva de 191 casos. RevColBras Cir. 2003;30(5):374:81.

3. Ramasamy A, Midwinter M, Mahoney P, Clasper J. Learning the lessons from conflict: pre-hospital cervical spine stabilization following ballistic neck trauma. Injury. 2009;40(12):1342-5.
4. Cruvinel Neto J, Dedivitis RA. Fatores prognósticos nos ferimentos cervicais penetrantes. Braz j otorhinolaryngol. 2011;77(1):121-4.

5. Golueke PJ, Goldstein AS, Sclafani SJ, Mitchell WG, Shaftan GW. Routine versus selective exploration of penetrating neck injuries: a randomized prospective study. J Trauma. 1984;24(12):1010-4

6. Hussain Zaidi SM, Ahmad R. Penetrating neck trauma: a case for conservative approach. Am J Otolaryngol. 2011;32(6):591-6.

7. McConnell DB, Trunkey DD. Management of penetrating trauma to the neck. Adv Surg. 1994;27:97-127.

8. Lourenção JL, Nahas SC, Margarido NF, Rodrigues Júnior AJ, Birolini D. Ferimentos penetrantes cervicais: análise prospectiva de 53 casos. RevHospClinFacMed São Paulo. 1998;53(5):234-41. 
9. Apffelstaedt JP, Müller R. Results of mandatory exploration for penetrating neck trauma. World J Surg. 1994;18(6):917-9; discussion 920.

10. Tisherman SA, Bokhari F, Collier B, Cumming J, Ebert J, Holevar M, et al. Clinical practice guideline: penetrating zone II neck trauma. J Trauma. 2008;64(5):1392-405.

11. Azuaje RE, Jacobson LE, Glover J, Gomez JA, Rodman GH Jr, Broadie TA, et al. Reliability of physical examination as a predictor of vascular injury after penetrating neck trauma. Am Surg. 2003;69(9):804-7.

12. Hospital do Trabalhador [homepage na Internet]. Tipos de atendimento no pronto socorro [acesso em 15 mai 2015]. Disponível em: http:www.hospitaldotrabalhador.saude.pr.gov.br

13. Gardner E, Gray DJ, O'Rahilly R. Anatomia: estudo regional do corpo humano. 4a ed. Rio de Janeiro: Guanabara Koogan; 1988.

14. Munera F, Danton G, Rivas LA, Henry RP, Ferrari MG. Multidetector row computed tomography in the management of penetrating neck injuries. Semin Ultrasound CT MR. 2009;30(3):195-204.

15. Múnera F, Soto JA, Palacio D, Velez SM, Medina E. Diagnosis of arterial injuries caused by penetrating trauma to the neck: comparison of helical CT angiography and conventional angiography. Radiology. 2000;216(2):356-62.

16. Meyer JP, Barrett JA, Schuler JJ, Flanigan DP. Mandatory vs selective exploration for penetrating neck trauma. A prospective assessment. Arch Surg, 1987;122(5):592-7.

17. Irish JC, Hekkenberg R, Gullane PJ, Brown DH, Rotstein LE, Neligan $P$, et al. Penetrating and blunt neck trauma: 10-year review of a Canadian experience. Can J Surg. 1997;40(1):33-8.

18. Biffl WL, Moore EE, Rehse DH, Offner PJ, Franciose RJ, Burch JM. Selective management of penetrating neck trauma based on cervical level of injury. Am J Surg. 1997;174(6):678-82.

19. Weigelt JA, Thal ER, Snyder WH 3rd, Fry RE, Meier DE, Kilman WJ. Diagnosis of penetrating cervical esophageal injuries. Am J Surg. 1987;154(6):619-22.
20. Asensio JA, Chahwan S, Forno W, MacKersie R, Wall M, Lake J, et al. Penetrating esophageal injuries: multicenter study of the American Association for the Surgery of Trauma. J Trauma. 2001:50(2):289-96.

21. Woo K, Magner DP, Wilson MT, Margulies DR. CT angiography in penetrating neck trauma reduces the need for operative neck exploration. Am Surg. 2005;71(9):754-8.

22. Stuhlfaut JW, Barest G, Sakai O, Lucey B, Soto JA. Impact of MDCT angiography on the use of catheter angiography for the assessment of cervical arterial injury after blunt or penetrating trauma. AJR Am J Roentgenol. 2005;185(4):1063-8.

23. Rathlev NK, Medzon R, Bracken ME. Evaluation and management of neck trauma. Emerg Med Clin North Am. 2007;25(3):679-94, viii.

24. Grewal H, Rao PM, Mukerji S, Ivatury RR. Management of penetrating laryngotracheal injuries. Head Neck. 1995;17(6):494502.

25. Sekharan J, Dennis JW, Veldenz HC, Miranda F, Frykberg ER. Continued experience with physical examination alone for evaluation and management of penetrating zone 2 neck injuries: results of 145 cases. J Vasc Surg. 2000;32(3):483-9.

26. Eddy VA. Is routine arteriography mandatory for penetrating injury to zone 1 of the neck? Zone 1 Penetrating Neck Injury Study Group. J Trauma. 2000;48(2):208-13; discussion 213-4.

27. Ferguson E, Dennis JW, Vu JH, Frykberg ER. Redefining the role of arterial imaging in the management of penetrating zone 3 neck injuries. Vascular. 2005;13(3):158-63.

Received on 10/01/2015

Accepted for publication 05/04/2015

Conflict of interest: none.

Source of funding: none.

Address for correspondence:

Melissa Mello Mazepa

E-mail: melissa.mazepa@gmail.com 